\title{
Association of Protein $Z$ with Prediabetes and Type 2
} Diabetes (Endocrinol Metab 2021;36:637-46, Yun-Ui Bae et al.)

\author{
Ji Hong You*, Yun-Ui Bae*, Ho Chan Cho \\ Department of Internal Medicine, Keimyung University Dongsan Hospital, Keimyung University School of Medicine, Daegu, \\ Korea
}

We would like to thank Pascreau et al. for reading our article carefully and thoroughly [1] and for providing interesting data from their research. As Pascreau et al. indicated, our findings are compatible with the other results that they mentioned [2]. We agree that the association of protein $\mathrm{Z}$ (PROZ) and type 2 diabetes mellitus (T2DM) is uncertain in patients with vascular complications. Since few studies have investigated PROZ and T2DM, accurate information on PROZ in the context of glucose dysmetabolism is currently limited. As mentioned in our article, $\mathrm{PROZ}$ was not found to be involved in the regulation of inflammatory [3], immune [4], and cell proliferation response pathways [5] related to glucose dysmetabolism in our bioinformatics analysis. Further studies are necessary to elucidate the hidden mechanism of PROZ in prediabetes and T2DM. When the role of $\mathrm{PROZ}$ in glucose dysmetabolism becomes clearer, its potential as a biomarker for prediabetes and T2DM will be ascertained.

Our study, however, had some differences from that of Pascreau et al. We mainly focused on identifying this cytokine as a potential biomarker of prediabetic status. We first checked fold changes in PROZ, and then evaluated PROZ levels in different subjects with normoglycemia, prediabetes, and T2DM. These two results showed consistent trends in PROZ levels. Our data

Received: 8 August 2021, Accepted: 19 August 2021

Corresponding author: Ho Chan Cho

Department of Internal Medicine, Keimyung University Dongsan Hospital, Keimyung University School of Medicine, 1035 Dalgubeol-daero, Dalseo-gu, Daegu 42601, Korea

Tel: +82-53-258-7217, Fax: +82-53-258-7209, E-mail: ho3632@naver.com also had some differences in the analyzed groups compared to the data mentioned by Pascreau et al. and the study by Heeb et al. [2]. We selected subjects with newly diagnosed T2DM in the cytokine microarray analysis and validation of PROZ. Most of our subjects did not have microvascular and macrovascular complications related to T2DM. The data provided by Pascreau et al. and the study by Heeb et al. [2] showed PROZ levels in subjects who had experienced ischemic stroke. We assume that these differences in the analyzed groups might contribute to differences in PROZ levels. Although a small number of subjects with cardiovascular disease (CVD) were included in our validation group (there were 0,2 , and 6 subjects with CVD in the normoglycemia, prediabetes, and T2DM groups, respectively), there were still significant differences in PROZ levels among the groups after excluding subjects with CVD. PROZ levels were lower in subjects with prediabetes $(1,491.90 \pm 378.40 \mathrm{pg} /$ $\mathrm{mL})$ and $\mathrm{T} 2 \mathrm{DM}(1,562.21 \pm 451.73 \mathrm{pg} / \mathrm{mL})$ than in subjects with normoglycemia $(1,864.07 \pm 450.83 \mathrm{pg} / \mathrm{mL})$ after excluding subjects with CVD $(P<0.001)$. Additionally, there were some differences in the PROZ levels of healthy subjects between our results and other studies $[2,6]$. We suggest that these gaps in the mean values of PROZ across studies might be influenced by

\section{Copyright $\odot 2021$ Korean Endocrine Society}

This is an Open Access article distributed under the terms of the Creative Commons Attribution Non-Commercial License (https://creativecommons.org/ licenses/by-nc/4.0/) which permits unrestricted non-commercial use, distribution, and reproduction in any medium, provided the original work is properly cited.

*These authors contributed equally to this work. 
ethnic differences across populations. Therefore, large-scale and diverse population-based studies are needed to investigate the potential of $\mathrm{PROZ}$ as a marker of glucose dysmetabolism.

The letter from Pascreau et al. is valuable for understanding our article. We deeply appreciate their comments, which have enriched our study.

\section{CONFLICTS OF INTEREST}

No potential conflict of interest relevant to this article was reported.

\section{ORCID}

Ji Hong You https://orcid.org/0000-0003-1544-7094

Yun-Ui Bae https://orcid.org/0000-0002-5084-5293

Ho Chan Cho https://orcid.org/0000-0003-0712-7728

\section{REFERENCES}

1. Bae YU, You JH, Cho NH, Kim LE, Shim HM, Park JH, et al. Association of protein $\mathrm{Z}$ with prediabetes and type 2 diabetes. Endocrinol Metab (Seoul) 2021;36:637-46.

2. Heeb MJ, Paganini-Hill A, Griffin JH, Fisher M. Low protein $\mathrm{Z}$ levels and risk of ischemic stroke: differences by diabetic status and gender. Blood Cells Mol Dis 2002;29:139-44.

3. Donath MY, Shoelson SE. Type 2 diabetes as an inflammatory disease. Nat Rev Immunol 2011;11:98-107.

4. Berbudi A, Rahmadika N, Tjahjadi AI, Ruslami R. Type 2 diabetes and its impact on the immune system. Curr Diabetes Rev 2020;16:442-9.

5. Chen C, Cohrs CM, Stertmann J, Bozsak R, Speier S. Human beta cell mass and function in diabetes: recent advances in knowledge and technologies to understand disease pathogenesis. Mol Metab 2017;6:943-57.

6. Vasse M, Guegan-Massardier E, Borg JY, Woimant F, Soria C. Frequency of protein $\mathrm{Z}$ deficiency in patients with ischaemic stroke. Lancet 2001;357:933-4. 